\title{
Identifying an efficient bacterial species and its genetic erosion for arsenic bioremediation of gold mining soil
}

\author{
Lamyai Neeratanaphan ${ }^{1,2 *}$, Tawatchai Tanee ${ }^{3}$, Alongklod Tanomtong ${ }^{1,4}$, \\ Bundit Tengjaroenkul ${ }^{1,5}$
}

\author{
${ }^{1}$ Research Group on Toxic Substances in Livestock and Aquatic Animals \\ Khon Kaen University, Thailand \\ ${ }^{2}$ Faculty of Science, Department of Environmental Science \\ Khon Kaen University, Thailand \\ ${ }^{3}$ Faculty of Environment and Resource Studies \\ Mahasarakham University, Thailand \\ ${ }^{4}$ Faculty of Science, Department of Biology \\ Khon Kaen University, Thailand \\ ${ }^{5}$ Faculty of Veterinary Medicine, Department of Veterinary Medicine \\ Khon Kaen University, Thailand
}

*Corresponding author's e-mail: hlamya@kku.ac.th

Keywords: arsenic-polluted soil, gold mining soil, efficient bacteria, genetic erosion.

\begin{abstract}
To improve bioremediation of arsenic (As) contamination in soil, the use of microorganisms to efficiently reduce As and their assessment of genetic erosion by DNA damage using genomic template stability (GTS) evaluation and using RAPD markers were investigated. The five sites examined for microorganisms and contaminated soils were collected from affected gold mining areas. The highest As concentration in gold mining soil is $0.72 \mathrm{mg} / \mathrm{kg}$. Microorganism strains isolated from the gold mining soil samples were tested for As removal capacity. Two bacterial isolates were identified by $16 \mathrm{~S}$ rRNA gene sequence analysis and morphological characteristics as Brevibacillus reuszeri and Rhodococcus sp. The ability to treat As in nutrient agar (NA) at $1,600 \mathrm{mg} / \mathrm{L}$ and contaminated soil samples at $0.72 \mathrm{mg} / \mathrm{kg}$ was measured at $168 \mathrm{~h}$, revealing more efficient As removal by B. reuszeri than Rhodococcus sp. (96.67\% and $94.17 \%$, respectively). Both species have the capacity to remove As, but B. reuszeri shows improved growth compared to the Rhodococcus $\mathrm{sp}$. B. reuszeri might be suitable for adaptation and use in As treatment. The results are in agreement with their genetic erosion values, with $B$. reuszeri showing very little genetic erosion (12.46\%) of culture in As concentrations as high as $1,600 \mathrm{mg} / \mathrm{L}$, whereas $82.54 \%$ genetic erosion occurred in the Rhodococcus sp., suggesting that Rhodococcus sp. would not survive at this level of genetic erosion. Therefore, B. reuszeri has a high efficiency and can be used for soil As treatment, as it is capable to tolerate a concentration of $0.72 \mathrm{mg} / \mathrm{kg}$ and as high as $1,600 \mathrm{mg} / \mathrm{L}$ in NA.
\end{abstract}

\section{Introduction}

Metal accumulation by solid substances can counteract metal mobilization in the environment if the solid substance is immobile. Arsenic (As) is an extremely toxic metalloid widely distributed in soil and water. The toxicity and mobility of As in the environment is dependent on the chemical form or species in which it exists. It is well known that inorganic As, such as arsenite and arsenate, are the most toxic As species. Additional anthropogenic source of mining activities, utilization of As-based pesticides or herbicides, and irrigation with As-contaminated water causes heavy contamination of soil, especially in farmland ecosystems (Jackson et al. 2006, Chen et al. 2008, Williams et al. 2009). Moreover, As is also commonly associated with sulfides, such as in sulfidic ore deposits. Other natural sources of As include volcanic activities, windborne soil particles, sea salt sprays and microbial volatilization of As (Frankenberger and Arshad 2002). As is a major contaminant of gold mining activities because the concentrations in the soil found to be high, polluting the environment hence causing environmental health problems. The concentrations of As in non-contaminated soils are typically well below $10 \mathrm{mg} / \mathrm{kg}$. Its presence at elevated concentrations in soils 
is due to both anthropogenic and natural inputs (Adriano 2001). In addition, As is known to have mutagenic and genotoxic effects on humans, and it has been associated with an increased risk of skin, kidney, lung, and bladder cancers (Shahedur et al. 2014). Cleaning the environment by removing these persistent and hazardous contaminants requires effective approaches allowing for precise restoration of polluted sites. Physico-chemical methods for remediation of metals from soils involve chemical extraction with acids or chelating agents, electrolysis, or size separation of the fraction of soil particles with the highest metal content (Page and Page 2002). Contamination of soils with heavy metals and metalloids, such as lead, cadmium, and arsenic, among others, represents a serious threat for the ecosystem and human health and requires the implementation of appropriate remedial measures. Microbial based technologies for metal extraction have become attractive because they are cost effective compared to chemical methods and might be applicable for a large number of inorganic pollutants (Hutchins et al. 1986). Bioremediation of As-contaminated soils has recently gained importance, in part because the processes promoting the bioremediation and biomethylation of As are still poorly understood. In addition, the bioremediation of As by microorganisms has been widely applauded because of the potential advantages of providing a cost-effective technology and an environmentally friendly method for heavy-metal removal (Valls and Lorenzo 2002). The removal of As from contaminated soils by applying anaerobic bioremediation techniques has been recently investigated by Chatain et al. (2005) and Ignatiadis and Battaglia-Brunet (2005).

There are several molecular techniques used to identify the genetic relationships and species of microorganisms. One of the most popular and efficient techniques is the sequence alignment of $16 \mathrm{~S}$ rRNA genes, which are highly conserved regions among an identical species and genus (Clarridge 2004, Neeratanaphan et al. 2015). This sequence can be successfully used for analysis of genetic diversity and species identification in bacteria (Gremion et al. 2003, Lindh et al. 2005, Flynn et al. 2013, Kang et al. 2013), including the evaluation of bacterial-heavy metal relatedness (Kozdrój and Van Elsas 2000, Park et al. 2006).

The gold mining industry has encountered problems with As for many years, because it is generated during gold extraction when arsenopyrite is broken down and it also and diffuses into soil and water, polluting the environment (Henke 2009). It can be distributed in either soil or water and transported to other places, polluting water resources and subsequently affecting water for daily consumption. Thus, organisms in the area near gold mines will adapt to their environment. Thailand has a gold mine located in the Wangsaphung district, Loei province, which affects the humans living in close proximity. Microorganisms are a suitable model to study possible impacts on human health if they are eukaryotes, allowing the examination of genetic erosion or genotoxicity.

A genotoxicity measurement caused by heavy metals in living things, including microorganisms, is mainly related to sensitivity and short response time (Gupta and Sarin 2009). The released pollutants can cause morbidity and mortality in the exposed organisms, possibly motivating order changes such as alterations to population dynamics and changes to biological diversity (An et al. 2012). The genotoxic effects depend on the oxidative state of the metal, its concentration and the duration of its exposure. In general, effects are more pronounced at higher concentrations and at longer exposure durations (Bhowmik 2000). Various molecular approaches, such as DNA fingerprinting based on inter simple sequence repeat (ISSR) and random amplified polymorphic DNA (RAPD) methods are generally used to effectively identify genetic relationships. The banding patterns can be scored for genomic template stability (GTS) evaluation to detect various types of previously identified DNA damage and mutations in bacteria, plants and animals (Neeratanaphan et al. 2014a, Neeratanaphan et al. 2014b). Gupta and Sarin (2009) used RAPD bands for GTS evaluation in Hydrilla verticillata and Ceratophyllum demersum and treated it with $\mathrm{Cd}, \mathrm{Hg}$ and $\mathrm{Cu}$ to demonstrate DNA damage. Zhou(2011) also used RAPD bands for GTS evaluation, identifying DNA damage in Euplotes svannus (Protozoa, Ciliophora) induced by nitrofurazone in marine ciliates.

In this work, the authors aim to study As contamination level in soil and to identify the species of microorganisms present in the soil and their effectiveness in As treatment for further use near gold mining areas. Additionally, genetic erosion in microorganisms impacted by As was evaluated by assessing DNA damage and inverting the GTS evaluation by studying a different RAPD marker.

\section{Materials and Methods}

\section{Sampling sites and As soil contamination measurements}

The five sampling sites are located in Wangsaphung district, Loei province of Thailand near the gold mine and are defined as the affected area, (Figure 1). As concentrations in the soil samples were determined with an atomic absorption spectrometry (AAS) model Analyst 300, Perkin-Elmer (Correira et al. 2003).

\section{Microorganism screening and species identification}

The microorganism strains were isolated from the soil sample observed to have the highest As concentration $(0.72 \mathrm{mg} / \mathrm{kg})$ at site 1 . The medium used for isolation was nutrient agar (NA) $(0.5 \%$ peptone, $0.5 \% \mathrm{NaCl}, 0.2 \%$ yeast extract, $0.2 \%$ beef extract and $1.5 \%$ agar, $\mathrm{pH} 7.0$, all $\mathrm{W} / \mathrm{V}$ ) containing $10 \mathrm{mg} / \mathrm{L}$ of sodium arsenate (Suresh et al. 2004). The microorganisms isolated included both fungi and bacteria. The fungi and bacteria obtained from the screening exercise were tested to determine whether fungi or bacteria were more As resistant in NA supplemented with 10, 100, 500, 1,000, 1,200, 1,400, 1,600 and $1,800 \mathrm{mg} / \mathrm{L}$ of $\mathrm{As}$, respectively. Finally, two bacteria isolates, B109 and B204, were observed to be more tolerant than fungi. Both isolates were identified by $16 \mathrm{~S}$ rRNA gene sequencing with dendrogram construction using MEGA5 program (Tamura et al. 2011) and genetic similarity values confirmed at the Collaborative Unit of Biological Science and Biotechnology of Mahidol University and Osaka University. Additionally, morphological characteristics were examined by scanning electron microscopy (SEM) using a LEO 1450VP. Specimens were prepared by fixation, dehydration and coating with a very thin layer of carbon (Lyman et al. 1990). 


\section{Testing of As remediation by Brevibacillus reuszeri (B109) and Rhodococcus sp. (B204)}

The As concentrations were selected from a reference noting that the highest As values found in water are $300 \mathrm{mg} / \mathrm{L}$ (Groundwater Research Center 2010), and the two bacteria were cultured in petri dishes containing nutrient broth (NB) contaminated with As at $300 \mathrm{mg} / \mathrm{L}$ and incubated at $37^{\circ} \mathrm{C}$. The remaining As in the NB were measured at 0, 24, 48, 72, 96, 120,144 and $168 \mathrm{~h}$ of culture using AAS detection in triplicate (Correira et al. 2003).

\section{Bioremediation of As in Gold Mining Soils}

In gold mining soils, As can be found at concentrations as high as $0.72 \mathrm{mg} / \mathrm{kg}$. Therefore, this concentration was selected for As remediation by the isolated bacteria at $0,24,48,72$, 96, 120, 144 and $168 \mathrm{~h}$. After As remediation, the remaining concentrations of As in the soil samples were measured by AAS, and the growth of bacteria in the soil samples was detected with the PEG-DOG method (Trung et al. 2011).

\section{RAPD marker, GTS evaluation and genetic erosion}

The bacteria were cultured in NA supplemented with As concentration levels of $0,100,500,1,000$ and 1,600 mg/L for $168 \mathrm{~h}$. DNA was extracted from bacterial cells using the Genomic DNA Extraction Kit (RBC Bioscience, Taiwan) following the manufacturer's instructions. The extracted DNA was assessed by $0.8 \%$ agarose gel electrophoresis and diluted to a final concentration of $20 \mathrm{ng} / \mu \mathrm{l}$. Two replicate experiments were performed by DNA extraction, RAPD banding patterns and analysis of DNA fingerprint profiles for GTS evaluation. Genetic erosion was converted from the GTS value.
Amplifications were performed on each sample in $25 \mu 1$ reactions containing GoTaq Green Master Mix (Promega), $0.5 \mu \mathrm{M}$ primers and $5 \mathrm{ng}$ DNA templates. Fifty RAPD primers were screened, and the successful primers are listed in Table 1. The reaction mixture was pre-denatured at $94^{\circ} \mathrm{C}$ for $3 \mathrm{~min}$, and the amplification was performed with the following 35 thermal cycles: denaturation for $1 \mathrm{~min}$ at $94^{\circ} \mathrm{C}$, annealing for $45 \mathrm{sec}$ at $40^{\circ} \mathrm{C}$, extension for $2 \mathrm{~min}$ at $72^{\circ} \mathrm{C}$; followed by a final extension for $7 \mathrm{~min}$ at $72^{\circ} \mathrm{C}$ using a Swift ${ }^{\mathrm{TM}}$ Maxi Thermal Cycler (Esco Micro Pte. Ltd.). Amplification products were detected by $1.2 \%$ agarose gel electrophoresis in TAE buffer and visualized using ethidium bromide staining. The resulted RAPD bands were used for dendrogram construction.

The RAPD bands from the successful amplifications were documented as diallelic characters: present $=1$ and absent $=0$. These banding data were used for GTS evaluation by percentages. The equation GTS $=100-(100 \times a / n)$ was used to calculate this value, in which $a$ is RAPD changes detected in each sample treated and $n$ is the number of total bands in the control (Atienzar et al. 1999). Genetic erosion was calculated from the GTS value.

\section{Results}

\section{As soil contamination measurements at the five sampling sites}

The concentrations of As in soils from the five sample sites ranged from the lowest, $0.04 \mathrm{mg} / \mathrm{kg}$, at site 5 to the highest, $0.72 \mathrm{mg} / \mathrm{kg}$, at site 1 . The average concentrations of As detected from three replicates at sites $1-5$ were $0.72 \pm 0.01,0.36 \pm 0.01$, $0.57 \pm 0.01,0.30 \pm 0.06$ and $0.04 \pm 0.01 \mathrm{mg} / \mathrm{kg}$, respectively, as shown in Table 2.

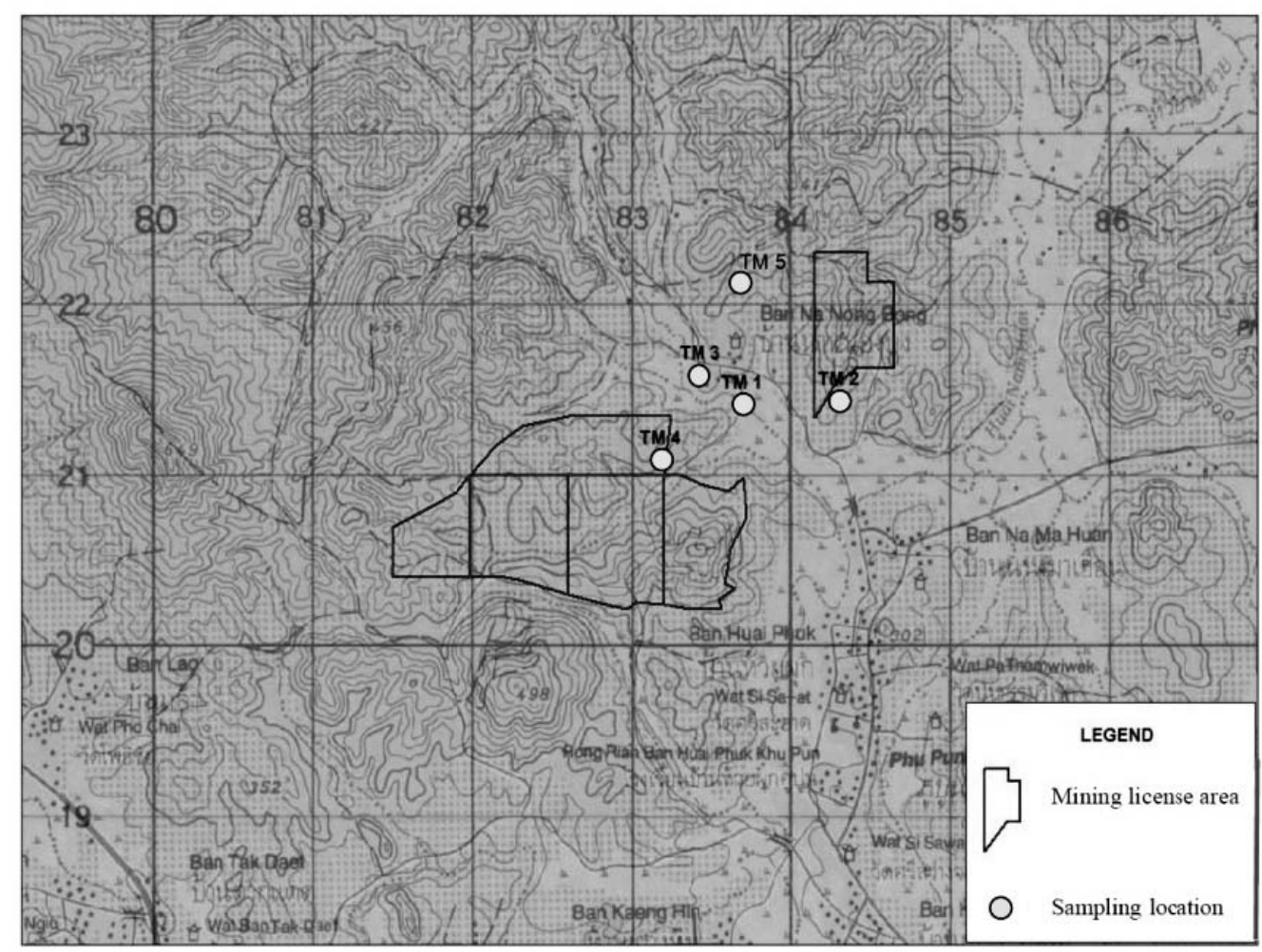

Fig. 1. An overview of the gold mining area and locations of the five sampling sites as shown by numbers 1 to 5 (Groundwater Research Center 2010) 
Table 1. Successful primer sequences for RAPD fingerprinting of the two bacteria isolates $B$. reuszeri (B109) and Rhodococcus sp. (B204)

\begin{tabular}{|c|c|c|c|c|c|c|c|}
\hline \multirow{2}{*}{ Primer } & \multirow{2}{*}{$\begin{array}{l}\text { Nucleotide sequence } \\
\left(5^{\prime}-3^{\prime}\right)\end{array}$} & \multicolumn{2}{|c|}{ Successful for } & \multirow{2}{*}{ Primer } & \multirow{2}{*}{$\begin{array}{c}\text { Nucleotide sequence } \\
\left(5^{\prime}-3^{\prime}\right)\end{array}$} & \multicolumn{2}{|c|}{ Successful for } \\
\hline & & B109 & B204 & & & B109 & B204 \\
\hline RA01 & CAGGCCCTTC & $\checkmark$ & - & RB16 & TTTGCCCGGA & $\checkmark$ & - \\
\hline RA02 & TGCCGAGCTG & $\checkmark$ & $\checkmark$ & RB17 & AGGGAACGAG & $\checkmark$ & $\checkmark$ \\
\hline RA03 & AGTCAGCCAC & $\checkmark$ & $\checkmark$ & RB20 & GGACCCTTAC & - & $\checkmark$ \\
\hline RA04 & AATCGGGCTG & $\checkmark$ & $\checkmark$ & $\mathrm{RC} 01$ & TTCGAGCCAG & $\checkmark$ & $\checkmark$ \\
\hline RA05 & AGGGGTCTTG & $\checkmark$ & - & $\mathrm{RC02}$ & GTGAGGCGTC & $\checkmark$ & - \\
\hline RA07 & GAAACGGGTG & $\checkmark$ & $\checkmark$ & $\mathrm{RC} 03$ & GGGGGTCTTT & - & $\checkmark$ \\
\hline RA09 & GGGTAACGCC & $\checkmark$ & $\checkmark$ & $\mathrm{RC04}$ & CCGCATCTAC & $\checkmark$ & - \\
\hline RA11 & CAATCGCCGT & $\checkmark$ & $\checkmark$ & $\mathrm{RC05}$ & GATGACCGCC & $\checkmark$ & $\checkmark$ \\
\hline RA13 & CAGCACCCAC & $\checkmark$ & $\checkmark$ & $\mathrm{RC} 06$ & GAACGGACTC & - & $\checkmark$ \\
\hline RA14 & TCTGTGCTGG & $\checkmark$ & $\checkmark$ & $\mathrm{RC08}$ & TGGACCGGTG & - & $\checkmark$ \\
\hline RA18 & AGGTGACCGT & $\checkmark$ & - & $\mathrm{RC} 10$ & TGTCTGGGTG & - & $\checkmark$ \\
\hline RA20 & GTTGCGATCC & $\checkmark$ & $\checkmark$ & $\mathrm{RC} 20$ & ACTTCGCCAC & $\checkmark$ & - \\
\hline RB01 & GTTTCGCTCC & - & $\checkmark$ & RD01 & ACCGCGAAGG & $\checkmark$ & - \\
\hline RB06 & TGCTCTGCCC & - & $\checkmark$ & RD02 & GGACCCAACC & $\checkmark$ & - \\
\hline RB07 & GGTGACGCAG & - & $\checkmark$ & RD03 & GTCGCCGTCA & $\checkmark$ & - \\
\hline RB08 & GTCCACACGG & $\checkmark$ & $\checkmark$ & RD04 & TCTGGTGAGG & $\checkmark$ & - \\
\hline RB10 & CTGCTGGGAC & $\checkmark$ & $\checkmark$ & RD11 & AGCGCCATTG & $\checkmark$ & - \\
\hline RB11 & GTAGACCCGT & $\checkmark$ & - & RD12 & CACCGTATCC & $\checkmark$ & - \\
\hline RB13 & TTCCCCCGCT & - & $\checkmark$ & RD14 & CTTCCCCAAG & $\checkmark$ & - \\
\hline RB14 & TCCGCTCTGG & - & $\checkmark$ & RD18 & GAGAGCCAAC & $\checkmark$ & - \\
\hline $\mathrm{RB} 13$ & TTCCCCCGCT & $\checkmark$ & - & RD20 & ACCCGGTCAC & $\checkmark$ & - \\
\hline RB15 & GGAGGGTGTT & $\checkmark$ & - & RE02 & GGTGCGGGAA & $\checkmark$ & - \\
\hline
\end{tabular}

Table 2. As contamination in gold mining soil (Mean \pm SD)

\begin{tabular}{|l|c|}
\hline \multicolumn{1}{|c|}{ Sampling sites } & As concentrations $(\mathrm{mg} / \mathrm{kg})$ \\
\hline Site 1 & $0.72 \pm 0.01$ \\
\hline Site 2 & $0.36 \pm 0.01$ \\
\hline Site 3 & $0.57 \pm 0.01$ \\
\hline Site 4 & $0.30 \pm 0.06$ \\
\hline Site 5 & $0.04 \pm 0.01$ \\
\hline
\end{tabular}

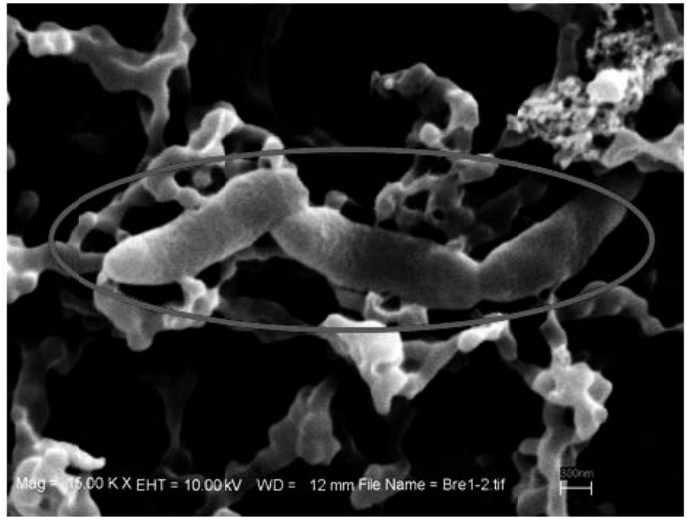

A

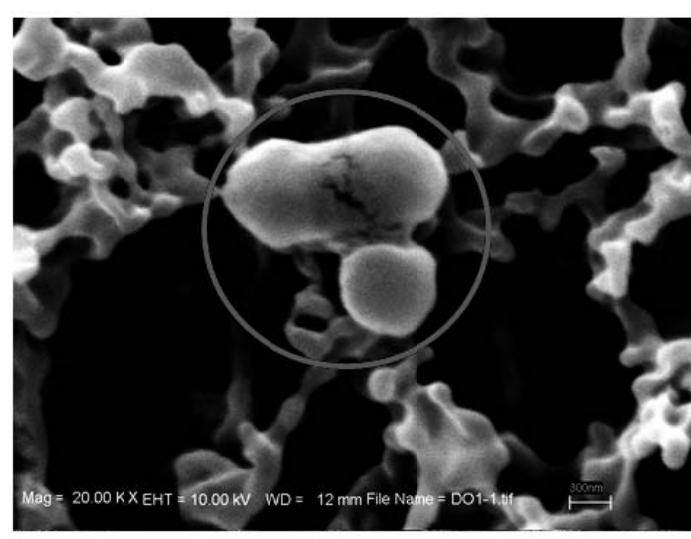

B

Fig. 2. Shapes of bacterial isolates $B 109$ (A) and B204 (B) from scanning electron microscopy (SEM) 
0.005 compared to Brevibacillus reuszeri and 0.000 compared to Rhodococcus erythropolis, R. zopfii, R. kunmingensis, $R$. pyridinivorans, $R$. gordoniae, $R$. rhodochrous and $R$. equi. The dendrogram separated B109 from $B$. reuszeri as shown in Figure 3 and included B204 in the branch of Rhodococcus erythropolis, $R$. zopfii, R. kunmingensis, R. pyridinivorans, $R$. gordoniae, $R$. rhodochrous and $R$. equi as shown in Figure 4.
Testing of As remediation by Brevibacillus reuszeri (B109) and Rhodococcus sp. (B204) in NB

Percentage of As removal by B. reuszeri was higher than by Rhodococcus sp. as shown in Table 3. Additionally, isolate B109 showed the fastest of As reduction in the NB from $24 \mathrm{~h}$ tight to $168 \mathrm{~h}$ from initial concentration of $300 \mathrm{mg} / \mathrm{L}$ as shown in Table 3 and Figure 5.

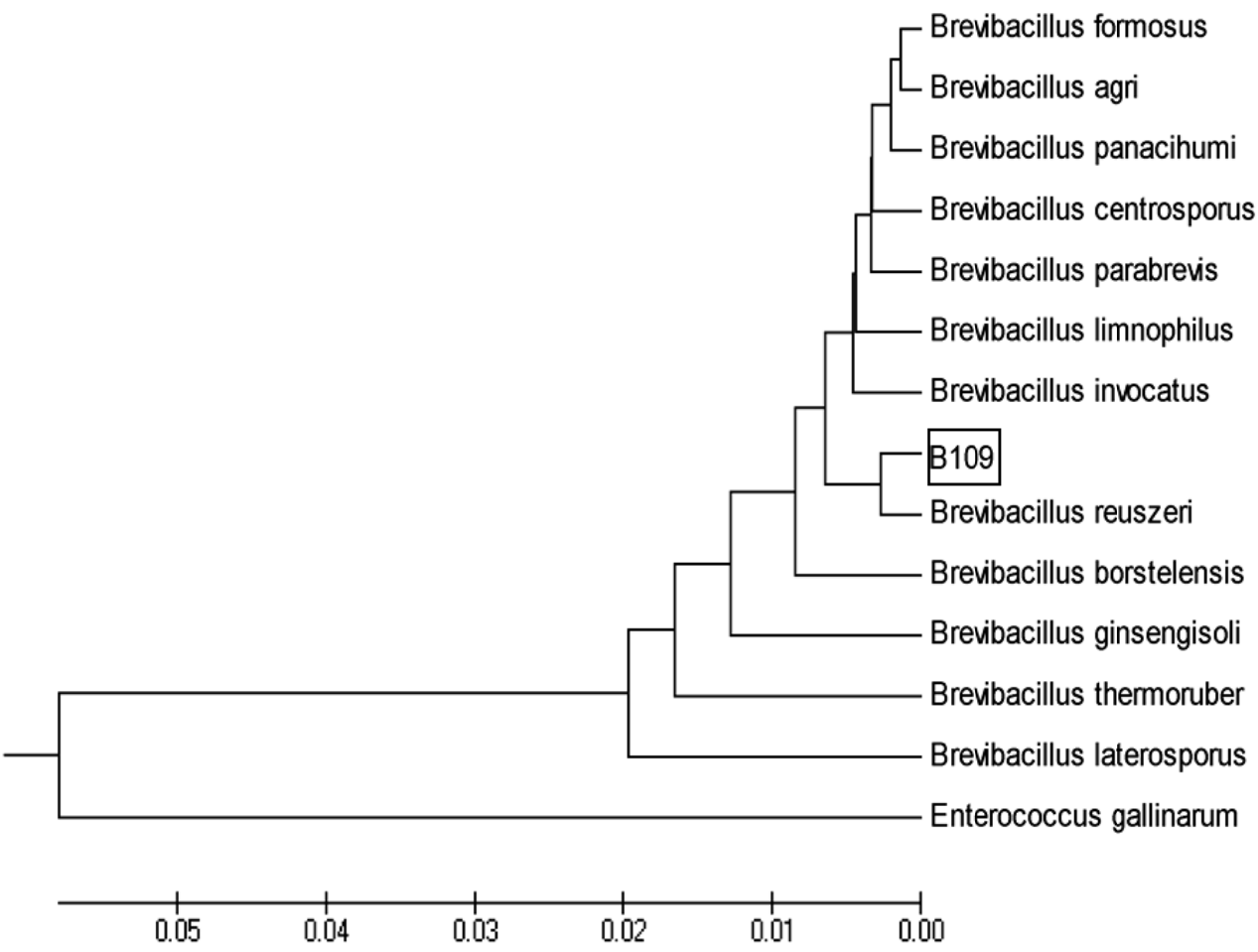

Fig. 3. The dendrogram constructed from 16S rRNA gene sequence analysis using the MEGA5 program (Tamura et al. 2011) showing the genetic relationship of isolate B109 compared to other bacteria in GenBank

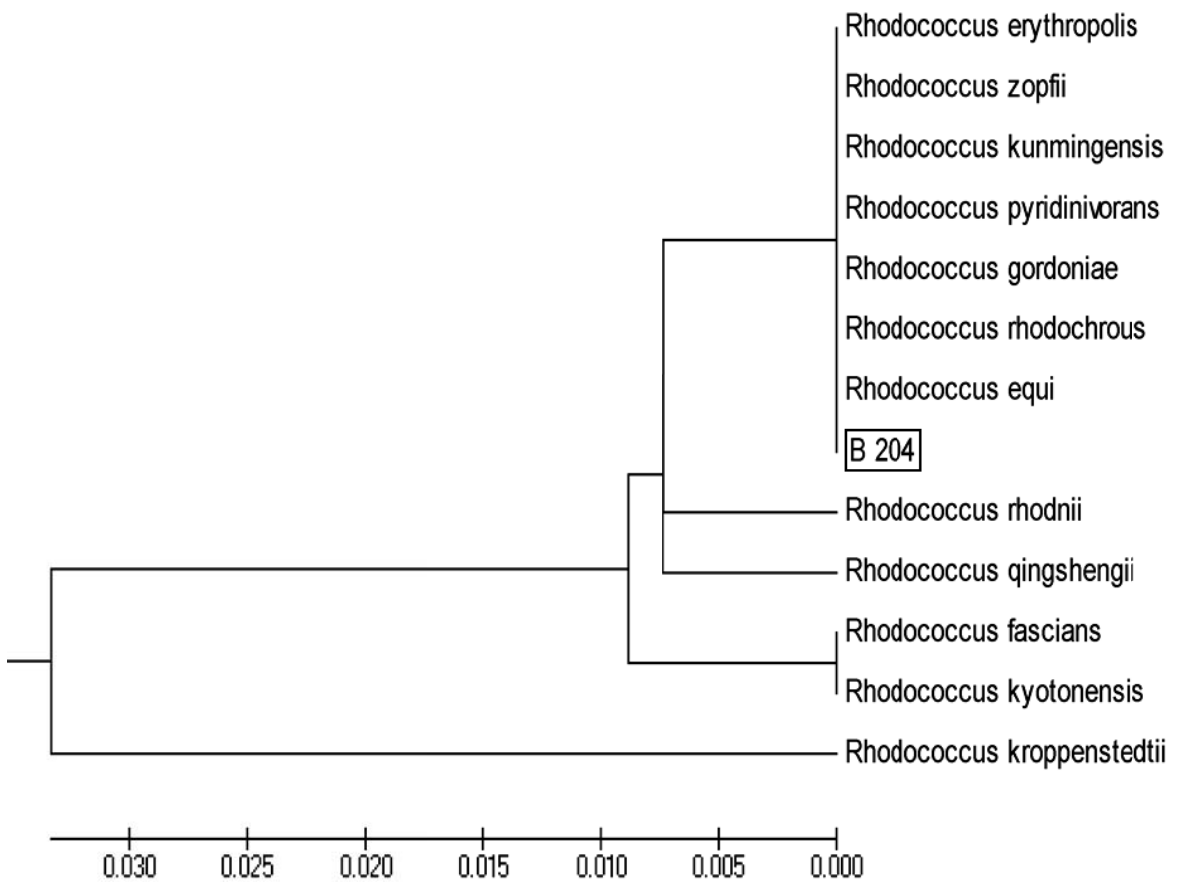

Fig. 4. The dendrogram constructed from $16 \mathrm{~S}$ rRNA gene sequence analysis using the MEGA5 program (Tamura et al. 2011) showing the genetic relationship of isolate B109 compared to other bacteria in GenBank 


\section{Bioremediation of As in gold mining soils}

Further remediation study using actual gold mining soil revealed that isolate B109 was superior to isolate B204 with more and faster removal as shown in Table 4 and Figure 6. Isolate B109 removed $96.67 \%$ of As from initial concentration of $0.72 \pm 0.01$ to $0.03 \pm 0.00 \mathrm{mg} / \mathrm{kg}$ in $168 \mathrm{~h}$. The concentration of As remediated by B109 after $168 \mathrm{~h}$ was below the level found in typical non contaminated soil of $10 \mathrm{mg} / \mathrm{kg}$.
The growth of the two bacteria after As remediation is shown in Figure 7. B. reuszeri has a larger capacity for As treatment than Rhodococcus sp., because the residual As in soil samples treated by $B$. reuszeri was less than in Rhodococcus sp. When the growth measurements were performed, the number of Rhodococcus sp. was higher than $B$. reuszeri during hours $0-144$, whereas after $144-168 \mathrm{~h}$ of incubation, the number of $B$. reuszeri bacteria was much higher than the Rhodococcus $\mathrm{sp}$. These results suggest that B. reuszeri could be adapted for As treatment.

Table 3. The concentrations of total As in NB after treatment by B. reuszeri (B109) and Rhodococcus sp. (B204) and the percentage of remediation (Mean $\pm \mathrm{SD}$ )

\begin{tabular}{ccccc}
\hline \multirow{2}{*}{ Time $(\mathrm{h})$} & \multicolumn{2}{c}{ B. reuszeri (B109) } & \multicolumn{2}{c}{ Rhodococcus sp. (B204) } \\
\cline { 2 - 5 } & $\begin{array}{c}\text { As remaining in NB } \\
(\mathrm{mg} / \mathrm{L})\end{array}$ & $\begin{array}{c}\% \text { As } \\
\text { removal }\end{array}$ & $\begin{array}{c}\text { As remaining in NB } \\
(\mathrm{mg} / \mathrm{L})\end{array}$ & $\begin{array}{c}\% \text { As } \\
\text { removal }\end{array}$ \\
\hline 0 & 300 & 0 & 300 & 0 \\
24 & $136.81 \pm 0.07$ & 54.40 & $243.74 \pm 0.10$ & 18.76 \\
48 & $132.51 \pm 0.50$ & 56.00 & $222.05 \pm 0.07$ & 24.32 \\
72 & $123.03 \pm 0.21$ & 58.99 & $187.87 \pm 0.02$ & 37.38 \\
96 & $112.53 \pm 0.01$ & 62.49 & $141.06 \pm 0.02$ & 52.98 \\
120 & $110.26 \pm 0.06$ & 63.25 & $132.18 \pm 0.03$ & 55.94 \\
144 & $98.72 \pm 0.15$ & 67.10 & $123.21 \pm 0.01$ & 58.93 \\
168 & $97.37 \pm 0.02$ & 67.55 & $117.96 \pm 0.01$ & 60.68 \\
\hline
\end{tabular}

Table 4. The concentration of total As in gold mining soil samples after treatment by B. reuszeri (B109) and Rhodococcus sp. (B204) (Mean \pm SD)

\begin{tabular}{ccccc}
\hline \multirow{2}{*}{ Time $(\mathrm{h})$} & \multicolumn{2}{c}{ B. reuszeri (B109) } & \multicolumn{2}{c}{ Rhodococcus sp. (B204) } \\
\cline { 2 - 5 } & $\begin{array}{c}\text { As remaining in soil } \\
\text { sample }(\mathrm{mg} / \mathrm{kg})\end{array}$ & $\begin{array}{c}\% \text { As } \\
\text { removal }\end{array}$ & $\begin{array}{c}\text { As remaining in soil } \\
\text { sample }(\mathrm{mg} / \mathrm{kg})\end{array}$ & $\begin{array}{c}\% \text { As } \\
\text { removal }\end{array}$ \\
\hline Control & $0.72 \pm 0.01$ & 0 & $0.72 \pm 0.01$ & $0.70 \pm 0.02$ \\
0 & $0.61 \pm 0.01$ & 15.28 & $0.37 \pm 0.02$ & 4.78 \\
24 & $0.23 \pm 0.01$ & 68.10 & $0.22 \pm 0.01$ & 69.45 \\
48 & $0.15 \pm 0.00$ & 79.17 & $0.18 \pm 0.01$ & 75.00 \\
72 & $0.07 \pm 0.00$ & 90.69 & $0.14 \pm 0.01$ & 80.56 \\
96 & $0.06 \pm 0.01$ & 91.67 & $0.08 \pm 0.00$ & 88.89 \\
120 & $0.04 \pm 0.00$ & 94.45 & $0.05 \pm 0.01$ & 93.06 \\
144 & $0.04 \pm 0.00$ & 95.14 & $0.04 \pm 0.00$ & 94.17 \\
\hline
\end{tabular}

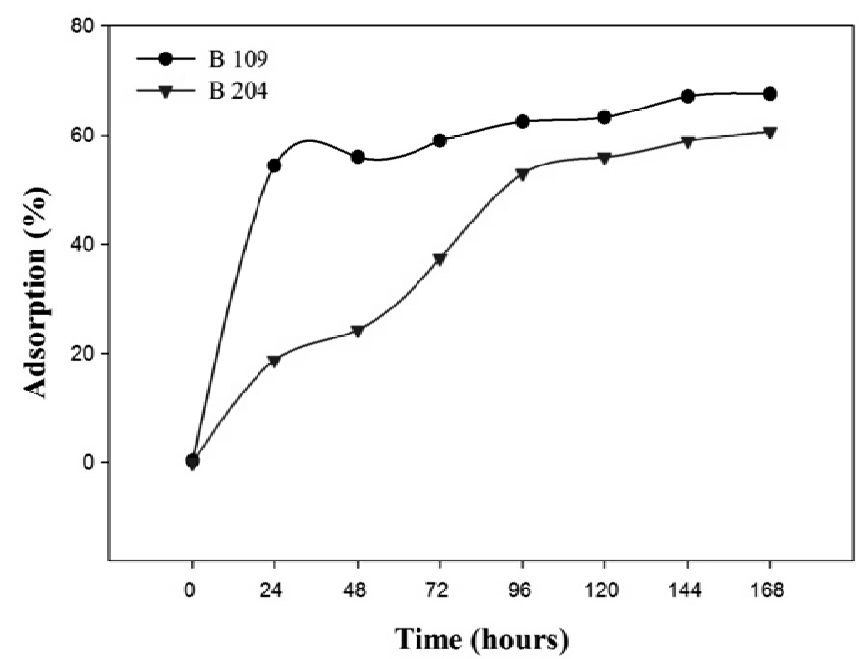

Fig. 5. As removal by $B$. reuszeri (B109) and Rhodococcus sp. (B204) in NB with an As concentration of $300 \mathrm{mg} / \mathrm{L}$ at 0,24 , $48,72,96,120,144$ and $168 \mathrm{~h}$ of incubation

\section{Assessment of DNA changes in B. reuszeri and Rhodococcus sp.}

The bacteria $B$. reuszeri and Rhodococcus sp. were cultured in NA containing As concentrations of 0, 100, 500, 1,000 and $1,600 \mathrm{mg} / \mathrm{L}$ for $168 \mathrm{~h}$. Both species were analyzed for DNA changes by GTS evaluation using RAPD markers. The 34 and 24 successful RAPD primers generated clear and analyzable fingerprinting profiles for $B$. reuszeri and Rhodococcus sp., respectively, and examples are shown in Figure 8. Only bands present in both samples for each experiment were included, and an identical number of 365 characteristics that were used for GTS evaluation. The GTS values are shown in Table 5 for $B$. reuszeri and Rhodococcus sp. The genetic erosion of the two bacteria are $0,7.48,6.33,7.17$, and 12.46 for $B$. reuszeri and $0,65.08$, $73.02,69.05$ and 82.54 for Rhodococcus sp. after exposure to As concentration of $0,100,500,1,000$ and $1,600 \mathrm{mg} / \mathrm{L}$, respectively. The values of genetic erosion and As concentration levels are correlated, such that when the As concentration was high, a large amount of genetic erosion occurred. 


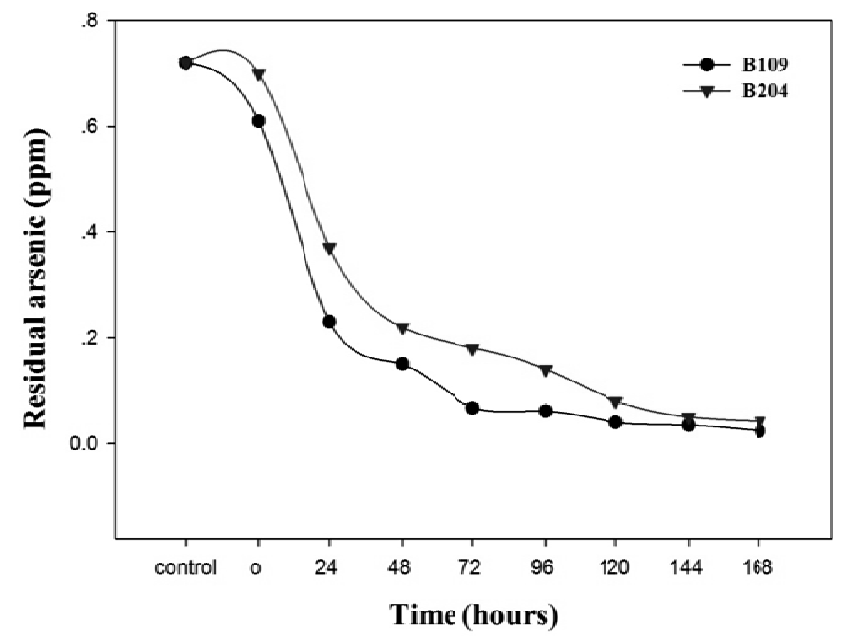

Fig. 6. Residual As in gold mining soil samples after treatment by $B$. reuszeri (B109) and Rhodococcus sp. (B204) after $0,24,48,72,96,120,144$ and $168 \mathrm{~h}$

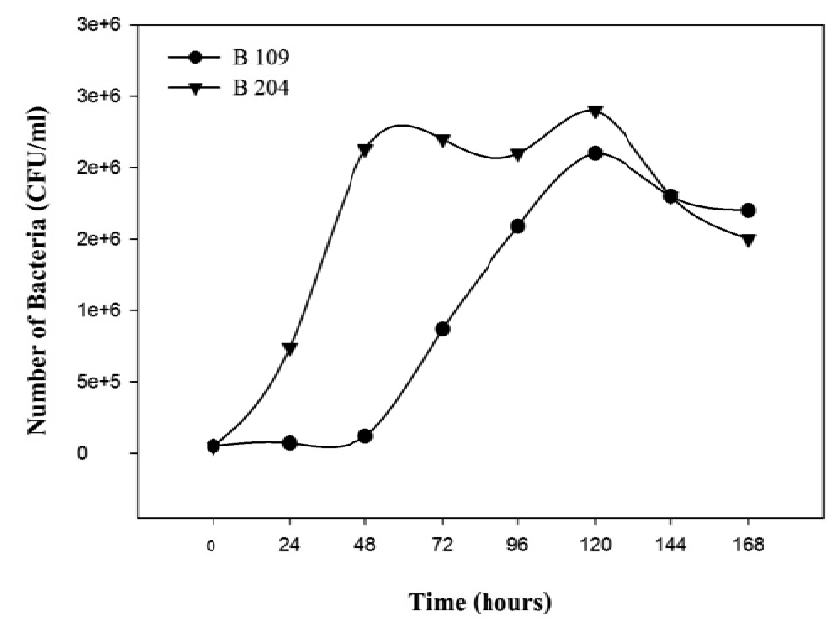

Fig. 7. Number of B. reuszeri (B109) and Rhodococcus sp. (B204) in gold mining soil samples of As treatment after $0,24,48,72,96,120,144$ and $168 \mathrm{~h}$

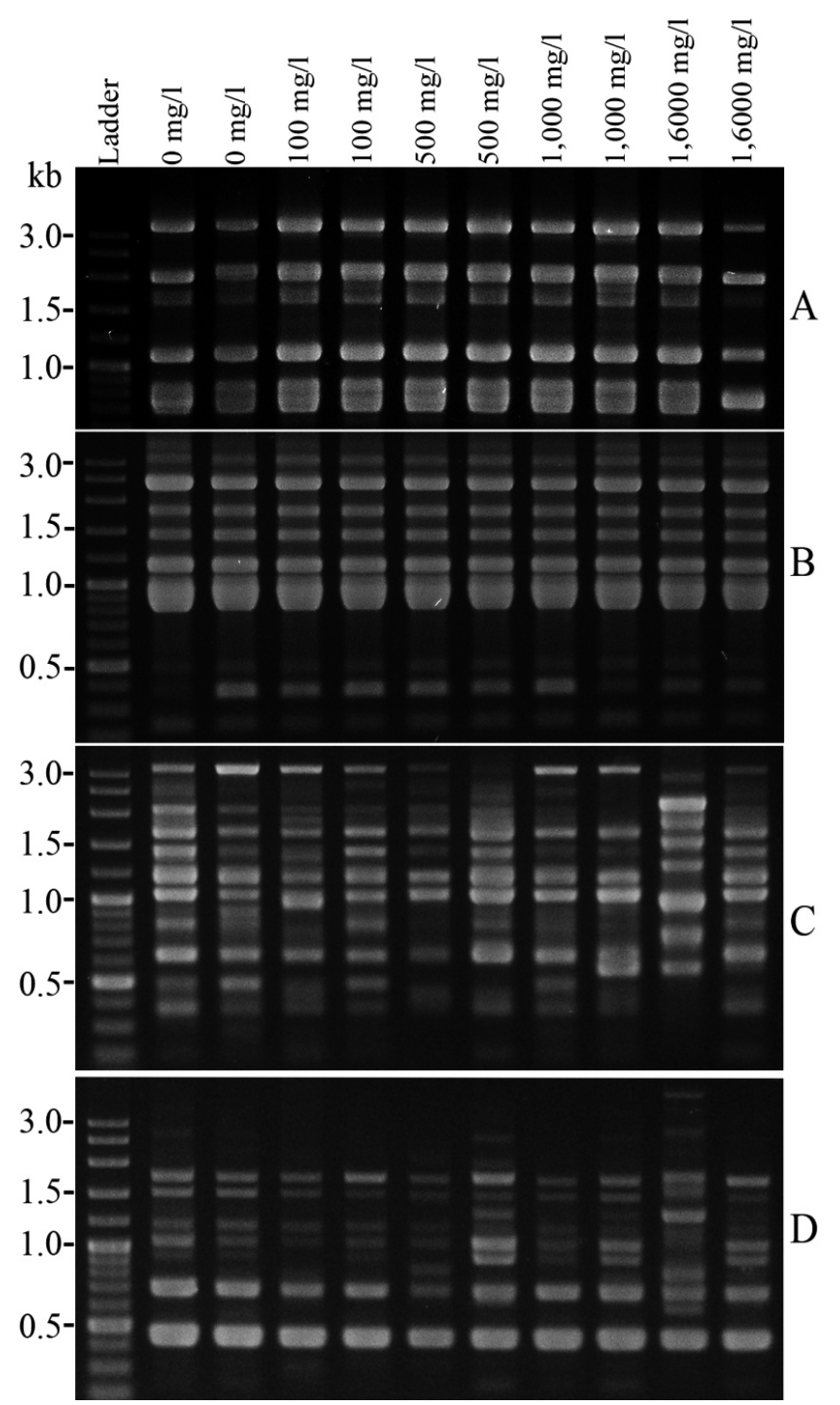

Fig. 8. Examples of RAPD banding patterns for As-treated bacteria from the primers CAGGCCCTTC (A) and CAATCGCCGT (B) for $B$. reuszeri, and AATCGGGCTG

(C) and CAGCACCCAC (D) for Rhodococcus sp.

Table 5. Genomic template stability (GTS) and genetic erosion evaluated from the RAPD banding patterns of the bacteria B. reuszeri (B109) and Rhodococcus sp. (B204) exposed to different concentration of As

\begin{tabular}{ccccc}
\hline $\begin{array}{c}\text { As concentration } \\
(\mathrm{mg} / \mathrm{L})\end{array}$ & $\begin{array}{c}\text { GTS }(\%) \\
\text { of B109 }\end{array}$ & $\begin{array}{c}\text { Genetic erosion } \\
\text { of B109 }\end{array}$ & $\begin{array}{c}\text { GTS }(\%) \\
\text { of B204 }\end{array}$ & $\begin{array}{c}\text { Genetic erosion } \\
\text { of B204 }\end{array}$ \\
\hline 0 & 100.00 & 0 & 100.00 & 0 \\
100 & 92.52 & 7.48 & 34.92 & 65.08 \\
500 & 93.77 & 6.33 & 26.98 & 73.02 \\
1,000 & 92.83 & 7.17 & 30.95 & 69.05 \\
1,600 & 87.54 & 12.46 & 17.46 & 82.54 \\
\hline
\end{tabular}

\section{Discussion}

It is well known that microorganisms can be used to remove heavy metals. Microorganisms have been widely applauded because of the potential advantages of providing a cost-effective technology and an environmentally friendly method for heavy-metal removal (Valls and Lorenzo 2002). The removal of As from contaminated soils by applying anaerobic bioremediation techniques has been recently investigated by Chatain et al. (2005) and Ignatiadis and BattagliaBrunet (2005). The problem of As contamination occurs in soil where majority of gold mine tailings pond sediment 
(Anderson and Cook 2004). Therefore, the authors screened for microorganisms to efficiently treat As contamination in areas near a gold mine that is defined as an affected area in Thailand. Microorganism screening was performed in soil samples from the hazardous areas, called sites $1-5$, and two groups, fungi and bacteria, were observed. When the fungi and bacteria were tested in NA to identify which has a higher capacity for As removal, two bacteria isolates were selected and called B109 and B204. Sequence analysis of 16S rRNA is frequently used for bacterial identification and has been widely reported (Gremion et al. 2003, Lindh et al. 2005, Kang et al. 2013). For the B109 16S rRNA, the genetic distance was 0.005 compared to Brevibacillus reuszeri in the dendrogram and showed a high similarity of 0.995 , so this isolate is likely to be B. reuszeri. For B204, there is no genetic distance between the seven species Rhodococcus erythropolis, R. zopfii, R. kunmingensis, R. pyridinivorans, $R$. gordoniae, $R$. rhodochrous and $R$. equi above. Therefore, it cannot be identified as a single species, but only as the genus Rhodococcus sp. When all of the data were examined, including the morphological characteristics assessed by SEM photos and 16S rRNA sequence, these isolates were concluded to be B. reuszeri and Rhodococcus sp.

When testing As remediation by $B$. reuszeri and Rhodococcus sp., the results showed that both species possess an ability for As treatment. B. reuszeri can remove $54.40-67.55 \%$ As over 24-168 h, and Rhodococcus sp. can remove $18.76-60.68 \%$ As over $24-168 \mathrm{~h}$ from a starting As concentration of $300 \mathrm{mg} / \mathrm{L}$ in NB. The experiment indicated more As removal after a long incubation of $168 \mathrm{~h}$. After this treatment, soil contaminated with As by gold mining was used to examine As removal in an environmentally relevant situation with a starting As concentration of $0.72 \mathrm{mg} / \mathrm{kg}$. The As percentages after treatment were 15.28-96.17\% over $24-168 \mathrm{~h}$ by $B$. reuszeri and $2.78-94.17 \%$ over the same time period by Rhodococcus sp. Similar to culturing in NB, after a long incubation, the amount of As removed by both B. reuszeri and Rhodococcus sp. was higher, as shown in Tables 3 and 4. However, when tested for growth under the same As concentration of $0.72 \mathrm{mg} / \mathrm{kg}$, B. reuszeri grew well, as shown by the graph in Figure 7, and from the time period of 144-168 h, the number of B. reuszeri bacteria was much higher than Rhodococcus sp. This indicated that B. reuszeri could be adapted and used for As treatment. The results are in agreement with the genetic erosion values, because $B$. reuszer $i$ showed little genetic erosion at $12.46 \%$ after $168 \mathrm{~h}$ and in an As concentration of $1,600 \mathrm{mg} / \mathrm{L}$, whereas $82.54 \%$ genetic erosion occurred in the Rhodococcus sp. The Rhodococcus sp. would not survive this level of genetic erosion. Therefore, B. reuszeri has a high efficiency and can be used for soil As treatment, with a concentration tolerance of $0.72 \mathrm{mg} / \mathrm{kg}$ and as high as $1,600 \mathrm{mg} / \mathrm{L}$ in NA.

Bioremediation of As by microorganisms has been widely accepted because of the potential advantage of providing a costeffective and environmentally friendly technology to remove heavy metals (Valls and Lorenzo 2002). The discovery of a new As treatment species, B. reuszeri, might be useful to research and ameliorate hazardous As contaminated areas worldwide, because its efficiency is higher than the concentration standard levels determined at $0.40 \mathrm{mg} / \mathrm{kg}$ by The US EPA Regional Screening Level; RSL (US EPA 2002).

\section{Conclusions}

Microorganism strains isolated from the gold mining soil samples were tested for As removal capacity. Two bacterial isolates were identified by $16 \mathrm{~S}$ rRNA gene sequence analysis and morphological characteristics as Brevibacillus reuszeri and Rhodococcus sp. Both species have the capacity to remove As, but $B$. reuszeri shows improved growth compared to Rhodococcus sp. Thus, B. reuszeri might be suitable for adaptation and use in As treatment. The results are in agreement with their genetic erosion values, with $B$. reuszeri showing very little genetic erosion (12.46\%) of culture in As concentrations as high as $1,600 \mathrm{mg} / \mathrm{L}$, whereas $82.54 \%$ genetic erosion occurred in the Rhodococcus sp., suggesting that Rhodococcus sp. would not survive this level of genetic erosion. Therefore, B. reuszeri has a high efficiency and can be used for soil As treatment, being able to tolerate a concentration of $0.72 \mathrm{mg} / \mathrm{kg}$ and as high as $1,600 \mathrm{mg} / \mathrm{L}$ in NA. In addition $B$. reuszeri, might be useful to research and ameliorate hazardous As contaminated areas worldwide.

\section{Acknowledgments}

This research was funded by the Research Group on Toxic Substances in Livestock and Aquatic Animals.

\section{References}

Adriano, D.C. (2001). Trace elements in the terrestrial environment, Springer, New York 2001.

Anderson, C.R. \& Cook, G.M. (2004). Isolation and characterization of arsenate-reducing bacteria from arsenic-contaminated sites in New Zealand, Current Microbiology, 48, 5, pp. 341-347.

An, L.H., Zheng, B.H., Wang, L.J., Zhang, Y.Q., Chen, H., Zhao, X.R., Zhang, L. \& Lei, K. (2012). Biomarker responses and genotoxicity in the mud snail (Bullacta exarata) as indicators of coastal contamination, Marine Pollution Bulletin, 64, 2, pp. 303-309.

Atienzar, F.A., Conradi, M., Evenden, A.J., Jha, A.N. \& Depledge, M.H. (1999). Qualitative assessment of genotoxicity using random amplified polymorphic DNA: comparison of genomic template stability with key fitness parameters in Daphnia magna expose to benzo[a] pyrene, Environmental Toxicology and Chemistry, 18, 10, pp. 2275-2282.

Bhowmik, N. (2000). Cytotoxic effects of lead compounds on plant systems, PhD thesis, University of Calcutta, Calcutta 2000.

Chatain, V., Bayard, R., Sanchez, F., Moszkowicz, P. \& Gourdon, R. (2005). Effect of indigenous bacterial activity on arsenic mobilization under anaerobic conditions, Environment International, 31, 2, pp. 221-226.

Chen, X.P., Zhu, Y.G., Hong, M.N., Kappler, A. \& Xu, Y.X. (2008). Effects of different forms of nitrogen fertilizers on arsenic uptake by rice plants, Environmental Toxicology and Chemistry, 27, 4, pp. 881-887.

Clarridge, J.E. (2004). Impact of 16S rRNA gene sequence analysis for identification of bacteria on clinical microbiology and infectious diseases, Clinical Microbiology Reviews, 17, 4, pp. 840-862.

Correira, P.R.M., Nomura, C.S. \& Oliviera, P.M. (2003). Multielement determination of cadmium and lead in urine, by simultaneous electrothermalatomic absorption spectrometry with end-capped graphite tube, Journal of Analytical Science, 19, 11, pp. 1519-1523.

Flynn, A.N., Lyndon, C.A. \& Church, D.L. (2013). Identification by 16S rRNA gene sequencing of an Actinomyces hongkongensis isolate recovered from a patient with pelvic actinomycosis, Journal of Clinical Microbiology, 51, 8, pp. 2721-2723. 
Frankenberger, W.T.Jr. \& Arshad, M. (2002). Volatilisation of arsenic. In: Frankenberger W.T.Jr. (ed.), Environmental chemistry of arsenic. Marcel Dekker, New York 2002.

Gremion, F., Chatzinotas, A. \& Harms, H. (2003). Comparative $16 \mathrm{~S}$ rDNA and 16S rRNA sequence analysis indicates that Actinobacteria might be a dominant part of the metabolically active bacteria in heavy metal-contaminated bulk and rhizosphere soil, Environmental Microbiology, 5, 10, pp. 896-907.

Groundwater Research Center (2010). Performance report of prevention in environmental impact and environmental monitoring of gold mining project (Phu Thap Pha, Loei province), Faculty of Technology, Khon Kaen University, Khon Kaen, Thailand 2010.

Gupta, M. \& Sarin, N.B. (2009). Heavy metal induced DNA changes in aquatic macrophytes: random amplified polymorphic DNA analysis and identification of sequence characterized amplified region marker, Journal of Environmental Science, 2, 5, pp. 686-690.

Henke, K.R. (2009). Arsenic: Environmental Chemistry, Health Threats And Waste Treatment, John Wiley \& Sons, (http://onlinelibrary. wiley.com/book/10.1002/9780470741122 (29.06.2016)).

Hutchins, S.D., Davidson, M.S., Brierley, J.A. \& Brierley, C.L. (1986). Microorganisms in reclamation of metals, Annual Review of Microbiology, 40, pp. 311-336.

Ignatiadis, I. \& Battaglia-Brunet, F. (2005). Applicability of anaerobic bacterial leaching as remediation technique for As-contaminated soils: batch, column and pilot experiments and economic assessment. In: Uhlmann, O., Annokkee, G.J \& Arendt, F. (eds.), Proceeding of the 9th International FZK/TNO Conference on Soil-Water Systems, Bordeau, October 2005.

Jackson, B.P., Seaman, J.C. \& Bertsch, P.M. (2006). Fate of arsenic compounds in poultry litter upon land application, Chemosphere, 65, 11, pp. 2028-2034.

Kang, S.H., Evans, P., Morrison, M. \& McSweeney, C. (2013). Identification of metabolically active proteobacterial and archaeal communities in the rumen by DNA- and RNA-derived 16S rRNA gene, Journal of Applied Microbiology, 115, 3, pp. 644-653.

Kozdrój, J. \& Van Elsas, J.D. (2000). Bacterial community DNA extracted from soils polluted with heavy metals, Polish Journal of Environmental Studies, 9, 5, pp. 403-407.

Lindh, J.M., Terenius, O. \& Faye, I. (2005). 16S rRNA gene-based identification of midgut bacteria from field-caught Anopheles gambiae sensu lato and $\mathrm{A}$. funestus mosquitoes reveals new species related to known insect symbionts, Applied Environmental Microbiology, 71, 11, pp. 7217-7223.

Lyman, C.E., Newbury, D.E., Goldstein, J.I., Williams, D.B., Romig, A.D., Armstrong, J.T., Echlin, P., Fiori, C.E., Joy, D.C., Lifshin, E. \& Klaus-Ruediger, P. (1990). Scanning electron microscopy, $X$-ray microanalysis, and analytical electron microscopy: a laboratory workbook, Plenum Press, New York 1990.
Neeratanaphan, L., Sudmoon, R. \& Chaveerach, A. (2014a). Assessment of genotoxicity through ISSR marker in Pistia stratiotes induced by lead, Environment Asia, 7, 2, pp. 99-107.

Neeratanaphan, L., Sudmoon, R. \& Chaveerach, A. (2014b). Genetic erosion in freshwater snail, Filopaludina martensi affected by lead and cadmium, Applied Ecology and Environmental Research, 12, 4, pp. 991-1001.

Neeratanaphan, L., Dechmon, S., Phonimdaeng, P., Khamon, P. \& Intamart, S. (2015). Removal of lead from wastewater contaminated with chemical synthetic dye by Aspergillus terreus, EnvironmentAsia, 8, 2, pp. 45-55.

Page, M. \& Page, C. (2002). Electroremediation of contaminated soils, Journal of Environmental Engineering, 128, 3, pp. 208-219.

Park, G.S., Kim, D.H., Lim, J.G. \& Ohga, S. (2006). Heavy metal concentration and identification of microorganisms in soil under roadside trees of Daejeon city; Korea, Journal of the Faculty of Agriculture, Kyushu University, 51, pp. 53-56.

Shahedur, R., Ki-Hyun, K., Subbroto, K.S., Swaraz, A.M. \& Dipak, K.P. (2014). Review of remediation techniques for arsenic (As) contamination: A novel approach utilizing bio-organisms, Journal of Environmental Management, 134, pp. 175-185.

Suresh, K., Prabagaran, S.R., Sengupta, S. \& Shivaji, S. (2004). Bacillus indicus sp. nov., an As-resistant bacterium isolated from an aquifer in West Bengal India, International Journal of Systematic and Evolutionary Microbiology, 54, 4, pp. 1369-1375.

Tamura, K., Peterson, D., Peterson, N., Stecher, G., Nei, M. \& Kumar, S. (2011). MEGA5: Molecular evolutionary genetics analysis using maximum likelihood, evolutionary distance, and maximum parsimony methods, Molecular Biology and Evolution, 28, 10, pp. 2731-2739.

Trung, T.T., Hetzer, A., Topfstedt, E., Gohler, A., Limmathurotsakul, D., Wuthiekanun, V., Peacock, S.J. \& Steinmetz, L. (2011). Improved culture-based detection and quantification of Burkholderia pseudomallei from soil, Transactions of the Royal Society of Tropical Medicine and Hygiene, 105, 6, pp. 346-351.

US EPA. (2002). Supplemental guidance for developing soil screening levels for superfund sites, Office of Solid Waste and Emergency Response, Washington DC 2002.

Valls, M. \& Lorenzo, V.D. (2002). Exploiting the genetic and biochemical capacities of bacteria for the remediation of heavy metal pollution, FEMS Microbiology Reviews, 26, 4, pp. 327-338.

Williams, P.N., Lei, M., Sun, G.X., Huang, Q., Lu, Y. \& Deacon, C. (2009). Occurrence and partitioning of cadmium, arsenic and lead in mine impacted paddy rice: Hunan, China, Environmental Science Technology, 43, 3, pp. 637-642.

Zhou, L., Li, J., Lin, X. \& Al-rasheid, K.A.S. (2011). Use of RAPD to detect DNA damage induced by nitrofurazone in marine ciliate, Euplotes vannus (Protozoa, Ciliphora), Aquatic Toxicology, 103, 4, pp. 225-232. 